\title{
A Novel Approach to Safe Special Fitness Testing in Judo Players
}

\author{
Wiesław Błach \\ University School of Physical Education \\ Tadeusz Ambroży \\ University of Physical Education \\ Zbigniew Obmiński \\ Institute of Sport-National Research Institute \\ Nikos Malliaronopoulos \\ University of London \\ Juliusz Migasiewicz \\ University School of Physical Education \\ Mariusz Ozimek \\ University of Physical Education \\ Jaromir Grymanowski \\ University of Rzeszow \\ Łukasz Rydzik ( $\square$ lukasz.gne@op.pl ) \\ University of Physical Education
}

\section{Research Article}

Keywords: judo, field tests, fitness, throws, head injuries

Posted Date: July 27th, 2021

DOI: https://doi.org/10.21203/rs.3.rs-726294/v1

License: (c) (i) This work is licensed under a Creative Commons Attribution 4.0 International License.

Read Full License 


\section{A Novel Approach to Safe Special Fitness Testing in Judo

3 Wiesław Błach ${ }^{1}$, Tadeusz Ambroży ${ }^{2}$ Zbigniew Obmiński $^{3}$, Nikos Malliaronopoulos ${ }^{4}$,

4 Juliusz Migasiewicz ${ }^{1}$, Mariusz Ozimek ${ }^{2}$, Jaromir Grymanowski ${ }^{5}$, Lukasz Rydzik ${ }^{2 *}$

$5 \quad{ }^{1}$ Faculty of Physical Education \& Sport, University School of Physical Education, 51-612

6 Wroclaw, Poland;

$7 \quad{ }^{2}$ Institute of Sports Sciences, University of Physical Education, 31-571 Krakow, Poland

$8{ }^{3}$ Department of Endocrinology, Institute of Sport-National Research Institute, Warsaw,

9 Poland

10

11 London, UK;

12

${ }^{5}$-College of Medical Sciences Institute of Physical Culture Studies, University of Rzeszow, Rzeszów, Poland;

Correspondence: lukasz.gne@op.pl; Tel.: +48-730-696-377

Abstract: Background: Measurements of physical fitness indices obtained in laboratory tests using an ergometer or a treadmill are very accurate, but they involve selected groups of muscles and do not reproduce the structure of the sport-specific exercise in judo. For this reason, researchers seek for the tests that use movements similar to the characteristic offensive techniques used during competitions (i.e. throwing). The most commonly recommended is the seoi-nage throwing test, known as SJFT (special judo fitness test). The aim of the study was to develop a new test in which uke is replaced by a dummy, in order to reduce the injury rate and ensure the safety of the participants. Methods: During the 3-week period, competitors from different weight classes performed at the beginning and then after 
the 2-week period one 1-minute series of continual dummy throws using the o-goshi technique and the seoi-nage technique. Post-exercise physiological responses (heart rate [HR] and blood lactate levels [La]) were evaluated. Results: Significant improvements were reported in o-goshi performance level after the training period. Physiological responses to exercise did not change significantly after training sessions. On both measurement days, postexercise La levels were similar for o-goshi and seoi-nage throws, whereas post-exercise HR was significantly greater after seoi-nage throws. Conclusions: The dummy throwing test can be a recommended alternative to uke throwing due to the elimination of the risk of injuries to practising athletes.

Keywords: judo, field tests, fitness, throws, head injuries,

\section{Background}

Combat sports constitute a group of sports that are often practiced in Poland. In this group, judo is the most popular sport practiced at both competitive and amateur level (1). It is necessary for the development of this sport to control the level of special and technical fitness in the implementation of basic elements that allow for success during the fight (2). During an official judo bout, lasting several minutes, various techniques are used to gain an advantage over the opponent. Winning before the time limit (4 minutes) is determined by the successful application of one of the following techniques: immobilization on the ground, choking, arm lock, and throwing the opponent on the mat in such a way that he or she falls on his back. It is also possible to lose a fight by disqualification or loss of points if the athlete is awarded a penalty for rule infringements during the fight $(3,4)$. Successful offensive actions during a judo fight require a lot of speed, strength, and a very good technique $(5,6)$. The first two physical characteristics can be evaluated with high accuracy using laboratory exercise tests 
with an ergometer and/or a treadmill (7). They allow for the estimation of the anaerobic or aerobic capacity depending on the time and load used for these efforts. However, laboratory results of elite judo athletes do not always show relationships with competitive performance (8). This may be due to the different motor and movement backgrounds used in laboratory tests of general fitness in relation to sports fight in judo. In these tests, selected groups of muscles of the upper or lower limbs are involved in the effort, while during judo fights the muscles of the whole body perform various short bouts of exercise at maximum intensity (912). Therefore, tests based on the performance of technical elements and parts of judo fight seem more appropriate. Furthermore, judo belongs to the group of open-skills sports. Therefore, in addition to physical fitness, the accuracy of decision-making in tactical problem-solving has a great effect on competitive performance and these skills should be developed through training (13). Seeking other predictors of success in judo revealed a wide range of technical skills as the basis, which is expressed in a repertoire of different types of throws used during competitions (14). For this reason, uchi-komi, nage-komi (drills of throws) and perfecting the skills of using them during sparring sessions (randori, kakarigeiko) play a dominant part in judo training programs (15). According to some authors, such exercises improve specific fitness and psychomotor abilities, although their excess may overload the hand muscles and decrease their strength (16).

Within the framework of the coaching control in judo, the analysis of the temporal and material structure of the fight is applied $(17,18)$, the technical-tactical indicators of activity, effectiveness, and efficiency of the fight are calculated (14,19-21), and biomechanical aspects of technique are evaluated $(22,23)$. There is also a need for ongoing monitoring of specific physical performance and effectiveness of techniques learned and speed of performing these techniques during the fight. Special and technical fitness tests have been used to evaluate such activities. They allow coaches to obtain data on the degree of technical skills acquired by 
athletes and at the same time indicate the level of development of strength, speed, and special endurance. When designing such tests, one should use the technical elements characteristic for a given sport (24). In judo, the development and standardization of the field tests should be based on the performance of basic offensive technical actions, i.e. throws.

A few dozen of different throwing techniques are known in judo $(25,26)$. Since the introduction of new rules (2013) for official competition, several studies have analyzed the effectiveness of these techniques in competitive settings both by gender and weight class (2729). Ippon seoi-nage, which is the most popular throwing technique in judo, was chosen to perform a reliable special fitness test $(30,31)$.

The procedure of such a test was first presented in a study by Sterkowicz and Ambroży on the physical fitness of ju-jitsu competitors (32). Furthermore, Sterkowicz standardized the test, determined its validity and reliability, supplemented it with an index of physical fitness, and implemented the test into practice while defining it as the Special Judo Fitness Test (SJFT)(33).

It was based on standardized sets of throws involving sparring partners using the seoinage technique. The advantages of the use of the test have been described in several publications emphasizing its effectiveness in the assessment of special preparation of judo competitors (34-42). The method of performing the test was as follows. After a 5-minute warm-up and performing the ippon-seoi-nage throws several times at a slow pace, three exercise periods (A: $15 \mathrm{~s} ; \mathrm{B}$ and $\mathrm{C}: 30 \mathrm{~s}$ each) were performed, separated by 10 -second breaks. In each period/set of throws, the thrower (tori) is evaluated based on the maximum number of ippon-seoi-nage throws performed on two partners (ukes A and B) standing on the mat $6 \mathrm{~m}$ apart. Both uke A and uke B should be of similar height and weight as the tori. Heart rate is measured immediately after and one minute following the test. This study evaluated the Index in SJFT: 


$$
\text { SJFT Index }=\frac{\text { Final } H R(b p m)+H R 1 \min (b p m)}{\text { Throws }(N)}
$$

where:

Final HR - heart rate recorded immediately after the test. HR1 min - heart rate obtained 1 minute after test. Throws - number of throws completed during the test. The response to exercise was recorded using S-610i heart rate monitor (43).

It can be speculated whether it is possible to perform this test with a different technique, for example using the favorite technique (tokui-waza) (44). Numerous studies have revealed a weight class-dependent total number of throws in the SJFT in three consecutive sets lasting 15-30-30 s separated by 10-second intervals. This allowed for developing reference ranges for both sexes by weight class and specific fitness level. The SFJT score has been shown to correlate with aerobic capacity as measured by laboratory exercise tests (45). The diagnostic value of SJFT and good reproducibility of results demonstrated in the test-

111 retest procedure suggest the use of this tool for the assessment of performance also in ju-jitsu 112 athletes (46), wrestlers $(47,48)$, and young judokas during preparation for important tournaments (49).

115 komi exercises has a harmful effect on the uke's health. A study using a dummy equipped

116 with sensors showed significant accelerations of the head on contact with tatami after 117 performing osoto-gari and ouchi-gari throws $(50,51)$. Such microtrauma is similar to repeated

118 blows to the head as in a boxing fight and can lead to damage to the brain and cervical spine

119 (52,53). The exposure of uke's brain to the acceleration associated with uke's rotation during 120 the throw was also studied for various tai-otoshi, seoi-nage, osoto-gari and ouchi-gari 
121 techniques.The highest mean accelerations were reported for osoto-gari and the lowest for

122 seoi-nage (54). During the throws on a special device imitating the human body performed by

123 a Japanese judo expert, the maximum accelerations for the head upon contact with the mat

124 exceeded many times the value of the gravitational acceleration $(\mathrm{G}=9.81 \mathrm{~kg} * \mathrm{~m} * \mathrm{sec}-1)$

125 (30,55). Judo athletes have mastered the techniques of falling to the ground (ukemi), which

126 significantly reduce the exposure of the uke's head to the impact with the mat (56), whereas in

127 less technically proficient judokas, repeated contact of the head with the mat during throws

128 poses a significant risk of injury $(30,57)$. Athletes under 20 years of age are mainly at risk of

129 serious neck and/or head injuries. Therefore, 3 years before the planned IO 2020 in Tokyo,

130 Japanese researchers called for more effective prevention of such cases both during training

131 and competitions (58).

In seeking the traditional judo throwing exercises (nage-komi) which are safer for the

133 thrown athletes and performance of special fitness tests, it is worth considering the possibility

134 of using grappling dummies, as it is the case in wrestling. A group of judo and combat sports

135 experts attempted to validate an alternative SJFT test using dummies and the o-goshi throwing

136 technique (Figure 1 and Figure 2).

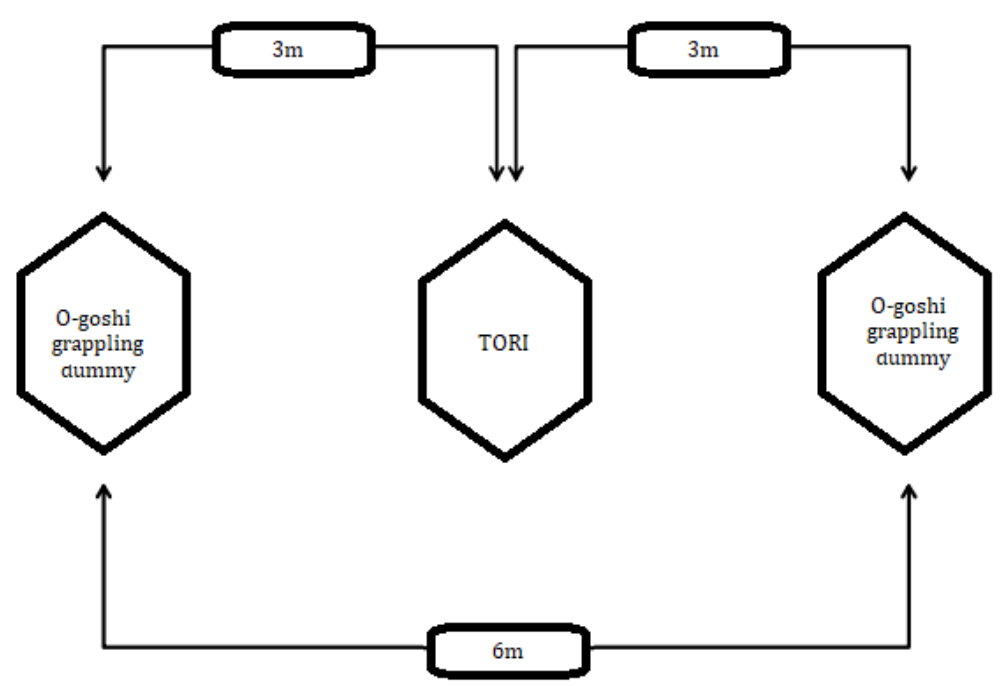


138

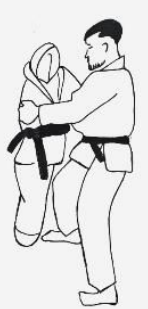

Figure 1. Positioning in the Special Fitness Test in Combat Sports

Source: author's own elaboration

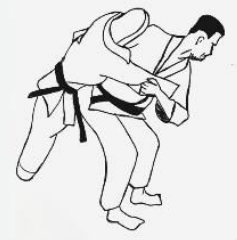

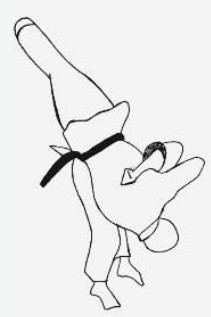

141

142

144 selected from each weight category, due to the availability of players during the training camp

Figure 2. O-goshi throw performed with a grappling dummy

Source: author's own elaboration

The aim of the study was to verify whether a shorter 1 -minute ( 2 times for 30 seconds) throwing test using two grappling dummies (not performed on uke partners) and the o-goshi technique, performed in a spatial arrangement as the SJFT test presented earlier has a similar diagnostic value and can be used alternatively to assess the special fitness in judo and ju-jitsu. The test was named Special Fitness Test in Combat Sports (SFTCS).

\section{Materials and Methods}

A group of fifteen athletes, three each from five weight classes (-60, -66, -81, -90, and $-100 \mathrm{~kg}$ ) aged $19-24$ years with a mean body height of $179.1 \pm 5.1 \mathrm{~cm}$, were examined during a 3-week training camp in the middle of the training and competition season (August). The athletes did not follow a restrictive diet, and therefore, the mean body weight before $(79.4 \pm 14.6 \mathrm{~kg})$ and after the camp $(78.7 \pm 14.0 \mathrm{~kg})$ was similar. Three participants were 
158 degree). Training experience of study participants was $8.6 \pm 0.97$ years. Body height was

159 measured with a Martin-type anthropometer. Body weight was measured on a Beurer glass 160 diagnostic scale type BG17, $\max 150 \mathrm{~kg}, \mathrm{~d}=100 \mathrm{~g}$ (Beurer GmbH Germany, limited edition $1612010)$.

162 Verification of the test was conducted in three stages:

1. At the beginning of the camp, on two consecutive days, the athletes performed the tests in randomized order according to the temporal formula $(15+30+30 \mathrm{~s})$ and spatial formula (distance between ukes or grappling dummies of 6 meters, tori thrower in the middle of them) just as it is the case during the classic SJFT test. Efforts consisting in the performance of a maximum number of throws using the o-goshi technique on a dummy weighing approximately a third of the athlete's body weight (in our study, dummies with heights ranging from 150 to $170 \mathrm{~cm}$ and weights from 20 to $40 \mathrm{~kg}$, respectively, were used), with the center of gravity located at a distance of 111 to $131 \mathrm{~cm}$ from the base, or throws using the seoi-nage technique involving alternately two partners (ukes) from the same weight category. The tests aimed to verify whether changing the partner to a grappling dummy and the throwing technique from seoi-nage to o-goshi would significantly affect the number of techniques performed by the athlete during the test. Before the first o-goshi test, the athletes performed preliminary trials several times to technically master the effort structure with the dummy, while they were previously familiarized with the seoi-nage technique performed on sparring partners. After completion of both tests performed according to the classic SJFT test formula, HR1 and HR2 were measured and the SJFT Index was calculated. The index of special fitness $=(\mathrm{HR} 1+\mathrm{HR} 2) /$ total throws was calculated for each test. goshi throws performed on the dummy (New SJFT) and seoi-nage throws with the 
183 involvement of two training partners (ukes) of the same weight category alternately, standing

184 between the tori, as it is the case during the classic SJFT test, were recorded. The Index SJFT 185 was also calculated.

3. After a 2-week period in which the athletes practiced both types of throwing every

187 few days, the throwing tests were repeated following the same procedure. Using an electronic pulse oximeter, heart rate was measured immediately after the completion of each test (HR1) and at 1 minute of post-test recovery (HR2). At 5 minutes after completion of the tests, capillary blood was obtained from the earlobe for determination of lactate levels (La) using Dr. Lange (Germany) test kit. The index of special fitness $=(\mathrm{HR} 1+\mathrm{HR} 2) /$ total throws was 192 calculated for each test.

Two-way analysis of variance (throw type $\mathrm{x}$ test date) was used to compare the mean variables at both dates, and then Bonferroni post-hoc test was applied. Calculations were performed on logarithmic data with significance set at 0.05 .

To evaluate test validity, the total number of throws and the SJFT Index were compared in tests performed according to the classic SJFT formula with the use of training partners and dummies. The correlations between the results of the SJFT test and the SFTCS performed at the beginning of the study and the results obtained in SFTCS at the end and the results of ju-jitsu athletes were then determined (59). The r-Spearman rank correlation was used. To determine the reliability of the proposed version of the test, the results of the tests performed at the beginning and the end of the training camp using the test (SFTCS) were compared by evaluating the differences and statistical error. 


\section{Results}

212 Descriptive statistics and results of statistical analysis for the study variables are presented in

213 Table 1.

214 Table 1.Task performance expressed as a number of throws, blood lactate levels $(\mathrm{mM})$ and 215 heart rate values (bpm).

\begin{tabular}{ccccc}
\hline Variable & Type of throw & Testing 1 & Testing 2 & p-value \\
\hline Total throws & seoi-nage & $21.1 \pm 0.9$ & $22.0 \pm 1.4$ & 0.488 \\
& o-goshi & $21.5 \pm 2.1$ & $23.9 \pm 1.7$ & 0.000 \\
& p-value & 1.00 & 0.003 & \\
\hline HR1 & seoi-nage & $174 \pm 10.1$ & $172.1 \pm 10.3$ & 1.00 \\
& o-goshi & $157.7 \pm 10.7$ & $154.8 \pm 10.7$ & 1.00 \\
& p-value & $\mathbf{0 . 0 0 0}$ & $\mathbf{0 . 0 0 0}$ & \\
\hline HR2 & seoi-nage & $131.3 \pm 6.1$ & $126.1 \pm 5.7$ & 0.205 \\
& o-goshi & $115.1 \pm 7.4$ & $107.6 \pm 6 \mathrm{~m} 7$ & 0.005 \\
& p-value & $\mathbf{0 . 0 0 0}$ & $\mathbf{0 . 0 0 0}$ & \\
\hline Index of & seoi-nage & $14.5 \pm 0.8$ & $13.6 \pm 1.1$ & 0.096 \\
fitness & o-goshi & $12.8 \pm 1.5$ & $11.0 \pm 1.0$ & 0.000 \\
& p-value & $\mathbf{0 . 0 0 0}$ & $\mathbf{0 . 0 0 0}$ & \\
\hline LA (lactate in & seoi-nage & $11.3 \pm 1.3$ & $11.2 \pm 0.9$ & 1.00 \\
blood) & o-goshi & $10.6 \pm 1.3$ & $10.6 \pm 1.0$ & 1.00 \\
& p-value & 0.446 & 0.552 & \\
\hline
\end{tabular}

216 Statistical analysis revealed a significant improvement in physical adaptations to the throwing

217 test performed with the o-goshi technique after approximately 2-week training. No

218 improvement was found for the seoi-nage test. After the training period, the index of fitness

219 significantly improved (by 14\%) in the o-goshi test, whereas in the seoi-nage test, the relative

220 improvement of $6 \%$ was not statistically significant. The greatest differences between the tests were documented for cardiovascular responses. With relatively small differences in the 
number of throws and metabolic changes reflected by blood lactate levels, post-exercise HR1

223 and HR2 values were significantly greater after seoi-nage throws.

224

225

226

227

228

229

230

Table 2. Comparison of total number of throws and SJFT Index in tests performed according to the classic SJFT formula using training partners and grappling dummies

\begin{tabular}{cccccc}
\hline Zmienne & $\mathbf{X}$ & SD & $\mathbf{x}_{\mathbf{1}}-\mathbf{x}_{\mathbf{2}}$ & $\mathbf{Z}$ & $\mathbf{p}$ \\
\hline SJFT -P(Tt) & 27,1 & 1,2 & 0,4 & 0,31 & 0,75 \\
SJFT - M(Tt) & 27,3 & 1,6 & 0,4 & 1,81 & 0,07 \\
SJFT -P(If) & 12,41 & 1,02 & 0,39 & & \\
SJFT - M(If) & 12,02 & 1,28 & &
\end{tabular}

If- Index of fitness, Tt-Total throws, SJFT- P- Special Judo Fitness Test person, SJFT- M-

Special Judo Fitness Test grappling dummy, Wilcoxion signed-rank test

As shown in Table 2, there were no statistically significant differences between the number of seoi-nage throws (performed with a partner) and o-goshi throws (performed on a dummy) and those performed according to the classic SJFT formula. There were also no statistically significant differences in Index of fitness values measured after the completion of the two tests presented (Table 2).

Table 3. Relationships between SJFT and SFTCS, in terms of the number of throws and Index of fitness, and relationships between the first and second trials of the SFTCS test in terms of a total number of throws and Index of SJFT.

\begin{tabular}{ccc}
\hline Variables & r/R & $\mathrm{p}$ \\
\hline SJFT(Tt) and SFTCS I & $\mathbf{0 . 8 5}$ & $<\mathbf{0 . 0 0 1}$ \\
SJFT(Tt) and the SFTCS II & $\mathbf{0 . 8 7}$ & $<\mathbf{0 . 0 0 1}$ \\
SJFT (If) and SFTCS I & $\mathbf{0 . 9 3}$ & $<\mathbf{0 . 0 0 1}$ \\
SJFT (If) and SFTCS II & $\mathbf{0 . 8 2}$ & $<\mathbf{0 . 0 0 1}$ \\
SFTCS I and SFTCS II & $\mathbf{0 . 8 1}$ & $<\mathbf{0 . 0 0 1}$ \\
SFTCS Index I and SFTCS Index II & $\mathbf{0 . 8 7}$ & $<\mathbf{0 , 0 0 1}$ \\
\hline
\end{tabular}


r-Pearson's coefficient, R - Spearman rank correlation coefficient, $\mathrm{p}$ - testing probability, numbers in bold denote statistical significance

As shown in Table 3, the correlations between the SJFT and SFTCS test are very high and statistically significant. Similarly, the correlations between the SFTCS test taken at the beginning and at the end of the period studied are very high and statistically significant.

Table 4. Coefficient of variation (CV\%) of the number of throws, index of special fitness (Index), and mean heart rate calculated from two time points after the tests (MHR)

\begin{tabular}{cccc}
\hline Test & $\begin{array}{c}\text { Total } \\
\text { throws }\end{array}$ & $\begin{array}{c}\text { Index of } \\
\text { fitness }\end{array}$ & MHR \\
\hline SFTCS & $8.45 \%$ & $11.67 \%$ & $3.1 \%$ \\
SJFT & $5.30 \%$ & $6.54 \%$ & $2.9 \%$ \\
\hline
\end{tabular}

As can be seen from Table 4, greater variability in the number of throws and Index of fitness between terms was observed for the SFTCS test.

\section{Discussion}

The results indicate that the SFTCS test proposed by the authors can be used as an alternative to the SJFT test. It was demonstrated that there were no differences between the number of seoi- nage throws (performed with a partner) and o-goshi throws (performed on a dummy) and those performed according to the classic SJFT formula. No differences in Index of fitness values were observed either. Such results demonstrate the validity of the SFTCS test. An additional confirmation of the thesis of the validity of the mentioned test are high correlations between the results of the SFTCS test and the results in the SJFT test, obtained both by judo and ju-jitsu athletes. The reliability (repeatability) of the test is evidenced by high correlations between SFTCS test performed at the beginning and at the end of the research period. 
Greater variability in the parameters of both techniques between the two test dates was

found for the SFTCS test. This fact does not translate into the inferior reliability of this test compared to the SJFT, but it is due to the significant improvement in the technical performance of the new task after the 2-week period. It should be noted that the precondition for the usability of the test-retest reliability procedure is to master the technique in such a way, that the so-called motor-learning effect, which occurs in the short-term period of adaptation to previously unused exercise tests, can be excluded.

The classification and pattern of physiological mechanisms of the body during the authors' SFTCS test is consistent with the course of the fight in judo and ju-jitsu $(33,59)$. The highest contribution of anaerobic processes in meeting the energy demands is observed at the initial stage of the exercise before aerobic transitions are activated in mitochondria, whereas the activity of the circulatory and respiratory systems reaches the level that corresponds to the oxygen demand (60). This is a period of oxygen debt. Therefore, this exercise can be qualified as the high-intensity anaerobic glycolytic-lactic exercise that determines the level of anaerobic endurance of the athlete studied.

A significant improvement of the o-goshi test results following a 2-week training is probably due to the improved technique of performing a new exercise test rather than a great improvement of fitness as indicated by the seoi-nage test parameters. It is worth looking for the reasons why the cardiovascular response and the rate of anaerobic glycolysis are higher after seoi-nage despite a similar number of throws in both tests. Considering the qualitative evaluation of the work performed by the thrower, it seems that a single seoi-nage throw requires the development of more power and energy expenditure. The total work done during the performance of the seoi-nage throw has two components: energy expenditure expressed in (Joul), potential energy expressed by the formula $\mathrm{Ep}=\mathrm{m}^{*} \mathrm{G}^{*} \mathrm{~h}$, where $\mathrm{m}$ is the mass of the athlete thrown, $\mathrm{G}=9.81 \mathrm{~kg} * \mathrm{~m} /($ second $) 2$, and $\mathrm{h}$ is vertical shift of body mass center of uke. The 
second component of energy expenditure is the uke rotation energy as given by the formula:

$292 \mathrm{Er}=0.5^{*} I^{*}(\omega) 2$ where $\mathrm{I}$ is the moment of inertia of the human body and $\omega$ is the rotational

293 speed expressed in radians. Also in this case, the Er value is expressed in Joules and is greater for the greater mass of the uke and faster performance of the throw.

In our study, the o-goshi throwing test elicits lower physiological responses, i.e., postexercise lactate levels and lower heart rate compared to the time-equivalent seoi-nage throwing test. This is likely to be due to the lower mechanical work or energy expenditure in the o-goshi test using a light $(33 \mathrm{~kg})$ dummy for all weight classes. In this case, with a single throw, the work required to verticalize the dummy is $E=33 \mathrm{~kg}^{*} 1.11 \mathrm{~m} * \mathrm{G}=359$ Joul. The second component is the work performed by the tori when inclining the body, and then the rotational energy of the dummy that can be ignored in the overall balance. A set of o-goshi throws is performed directly one after another with minimal rests, and therefore the effort can be considered continuous and uniform. Seoi-nage throws are more energy-intensive and are separated by an average of 3-second breaks, which qualifies the overall test as high-intensity interval exercise.

Since specific judo fitness has not been studied in the literature using 1 -minute (2 times 30s) sets of throws, post-training changes in fitness in judokas recorded by other researchers are difficult to compare with those obtained in our study. This applies to both seoi-nage and o-goshi throws. Regarding changes in physical fitness after training periods, the literature presents examples of positive effects. Post-training improvements in field test performance have been reported in many studies(18,39,61). After six weeks of training, a relative increase of $3.7 \%$ in total throws was reported in the SJFT test (34). In this study, the mean total throws in sets B and C lasting 60 seconds in total was 20.9 before the training and 21.7 after training, which is very similar to the results obtained in our study for 1-minute exercise. According to Sterkowicz et al. (34), the improvements in post-training performance 
in the SJFT are more likely to be due to neuromuscular adaptation and improvement in seoi-

317 nage technique (especially the speed of the grip-and-throw sequence) than changes in the cardiorespiratory system. On the other hand, in addition to the effect of good technique, the performance level significantly depends on anaerobic power and aerobic capacity, as evidenced by positive correlation coefficients between total throws and indices of laboratory tests (42). The data on total throws in the SJFT allowed for developing fitness standards for

322 female (36) and male athletes (37), taking into account age categories, that classify the subjects' fitness as poor to excellent. However, based on total throws in comparative observations conducted by many authors, it is apparent that one of the key elements determining the number of throws in SJFT may be weight-dependent agility (agility). The level of this trait determines the speed of the run with sequential changing of run direction. Studies have shown that body mass (38) and agility (39) are independent predictors of total throws in SJFT.

It is worth emphasizing that the studies cited above overlook some important

330 determinants affecting the level of SJFT performance. One of them is the forced weight 331 reduction preceding the competition. The introduction of a restrictive diet $(2192 \mathrm{Kcal} / \mathrm{day})$ for a group of athletes with a mean body weight of $75.9 \mathrm{~kg}$ resulted in a decreased body weight to a mean value of $72.7 \mathrm{~kg}$ and a statistically significant deterioration in mean total throws (26.3 vs. 31) and greater post-exercise cardiovascular responses (62). In our study, the mean posttraining decreased body weight by less than $1 \mathrm{~kg}$ can be neglected as a factor affecting physical fitness.

In the light of our findings and those documented by other authors, it can be observed that throwing tests using the conventional SJFT test $(15+30+30)$ and its modification $(60 \mathrm{~s})$ and the o-goshi technique using a dummy (60s) performed in the field conditions can be

340 useful for the assessment of the general level of special physical fitness. Furthermore, throws 
with a dummy can be recommended in training because they eliminate health risks in judokas.

342 However, athletes should be provided with access to dummies of various weights. In the

343 absence of a dummy, it is possible to return to the sparring or test with the involvement of

344 sparring partners (ukes). Bearing this in mind, it is advisable not to use such techniques with

345 tired athletes, because during or immediately after intensive exercise, greater angular

346 accelerations are observed in ukes, consequently leading to the accumulation of micro-

347 traumas that are harmful to the central nervous system (63).

\section{Conclusions}

349 The specific movements performed during the judo fight justify the introduction of tests based

350 on throws to the examination of special fitness. The use of the o-goshi throw and the 351 introduction of grappling dummies does not change the diagnostic value of the SJFT test. The

352 classification and pattern of physiological mechanisms of the body during the authors' special

353 fitness test (SFTCS) is consistent with the course of the fight in judo and ju-jitsu. The

354 proposed SFTCS test offers an alternative to the SJFT test and represents a selective, valid,

355 reliable, and simple diagnostic tool for testing the special fitness of judo and ju-jitsu athletes.

356 A specific throwing test using a dummy can offer a convenient tool for both the assessment of

357 the athlete's physical fitness and in throwing training, as it does not require a partner and does

358 not pose a risk of injury to the athlete.

\section{Practical implications.}

360 The special fitness test (SFTCS) proposed in this study can be a tool for selection and

361 interpretation of athletes' performance in both judo and ju-jitsu because it offers a reliable,

362 valid, and user-friendly research tool. The proposed test can be used in a safe way and without

363 special equipment for the comprehensive assessment of the level of preparation used for the 
364 comprehensive assessment of the level of preparation in terms of special fitness in judo and 365 ju-jitsu.

Declarations

370 Abbreviations: SJFT- P- Special Judo Fitness Test person, SJFT- M- Special Judo Fitness

371 Test grappling dummy

372 Ethics approval and consent to participate: The study was conducted according to the

373 guidelines of the Declaration of Helsinki and approved by the Ethics Committee of Regional 374 Medical Board in Krakow (approval No. 287/KBL/OIL/2020). Informed consent was 375 obtained from all subjects involved in the study.

376 Consent for publication: Not Applicable

377 Availability of data and material: All data are available in the manuscript

378 Competing interests: The authors declare no conflict of interest

379 Funding: This research received no external funding.

380 Authors' contributions: Conceptualization, W.B., T.A. and Ł.R.; methodology, W.B., T.A., 381 Ł.R., Z.O.; software, J.M., N.M.; validation, W.B., T.A., Ł.R. and Z.O.; formal analysis, T.A., 382 J.M., Ł.R.; investigation, W.B.; re-sources, W.B., T.A., Z.O., Ł.R.; data curation, W.B., J.G.; 383 writing - original draft preparation, W.B., Z.O., Ł.R., T.A..; writing-review and editing, 384 W.B., Z.O., Ł.R., T.A., M.O.; visualization, J.M.; su-pervision, T.A., Ł.R., N.M.; project 385 administration, W.B.; funding acquisition, W.B., T.A. 
Acknowledgments: We would like to thank the players of the AZS AWF Wrocław sports club for their participation in the research

\section{References}

392 1. Biernat E, Krzepota J, Sadowska D. Martial Arts as a Form of Undertaking Physical Activity in Leisure Time Analysis of Factors Determining Participation of Poles. Int J Environ Res Public Health [Internet]. 2018 Sep 12;15(9):1989. Available from: http://www.mdpi.com/1660-4601/15/9/1989

2. Weineck J. Futebol Total: Physical training in soccer. São Paulo Phorte. 2004;555.

3. Calmet M, Pierantozzi E, Sterkowicz S, Takito MY, Franchini E. Judo rules: searching for a wind of changes. Int J Perform Anal Sport. 2017 Nov;17(6):863-71.

4. Samuel RD, Basevitch I, Wildikan L, Prosoli R, McDonald K. Please stop changing the rules! the modifications of judo regulations as a change-event in judokas' and coaches' careers. Sport Soc. 2020 Apr;23(4):774-94.

5. Koyunlu A, Da Ö, Lu ĞLIOĞ, Zdal MÖ. Comparison of Physical Fitness and Respiratory Parameters of Elite Wrestlers and Judokas. 2020;360-5.

6. Torres-Luque G, Hernández-García R, Escobar-Molina R, Garatachea N, Nikolaidis P. Physical and Physiological Characteristics of Judo Athletes: An Update. Sports. 2016 Mar;4(1):20. 
8. Borkowski L, Faff J, Starczewska-Czapowska J. Evaluation of the aerobic and anaerobic fitness in judoists from the Polish national team. Biol Sport. 2001;18(2):10717.

9. Segedi I, Sertić H, Franjić D, Kuštro N, Rožac D. Analysis of judo match for seniors. J Combat Sport Martial Arts [Internet]. 2014 Dec 18;5(2):57-61. Available from: http://6036.indexcopernicus.com/abstracted.php?level=5\&ICID=1141976

10. Obmiński Z, Witek K, Lerczak K, Borkowski L, Szczepańska B, Błach W. Work-torest ration during three repeated judo struggles separated by short intermissions. A preliminary study. J Combat Sport Martial Arts. 2014;5:53-6.

11. Sterkowicz-Przybycień K, Miarka B, Fukuda DH. Sex and Weight Category Differences in Time-Motion Analysis of Elite Judo Athletes: Implications for Assessment and Training. J Strength Cond Res [Internet]. 2017 Mar;31(3):817-25. Available from: https://journals.lww.com/00124278-201703000-00029

12. Soriano D, Irutia A, Tarragó R, Tayot P, Millá-Villaroel R, Iglesiss X. Time-motion analysis during elite judo combats (defragmenting the gripping time). Arch Budo. 2019;15:33

13. Miarka B, Brito CJ, Amtmann J, Córdova C, Bello F dal, Camey S. Suggestions for Judo Training with Pacing Strategy and Decision Making by Judo Championship Phases. J Hum Kinet [Internet]. 2018 Oct 15;64(1):219-32. Available from: 
Jun;106(3):859-69. Available from:

http://journals.sagepub.com/doi/10.2466/pms.106.3.859-869

433

434

435

436

437

15. Ambroży T. Struktura tren ingu ju-jitsu. Warszawa: Biblioteka Trenera. Centralny Ośrodek Sportu; 2008.

16. Obminski Z, Litwiniuk A, Staniak Z, Zdanowicz R, Weimo Z. Intensive specific maximal judo drills improve psycho-motor ability but may impair hand grip isometric strength. Ido Mov Cult. 2015;15(2):52-8.

17. Sterkowicz S, Maslej P. An evaluation of the technical and tactical aspects of judo matches at the seniors level. Div Combat Sport. 1999;

18. Marcon G, Franchini E, Jardim JR, Barros Neto TL. Structural Analysis of Action and Time in Sports: Judo. J Quant Anal Sport [Internet]. 2010 Jan 15;6(4). Available from: https://www.degruyter.com/document/doi/10.2202/1559-0410.1226/html

19. Adam M, Smaruj M, Pujszo R. Charakterystyka indywidualnego przygotowania techniczno-taktycznego zawodników judo, zwycięzców Mistrzostw Świata z Paryża w 2011 oraz z Tokio w 2010 roku. IDO Mov Cult J Martial Arts Anthr. 2012;12:60-9.

20. Smaruj M., Laskowski R. AM. Częstotliwość i efektywność ataków zawodniczek judo na podstawie walk w czteroletnim okresie treningowym. In: Sozański H, Perkowski K, Śledziewski D (red), Proces doskonalenia treningu i walki sportowej, Tom 5. Warszawa; 2008. p. 102-6.

21. Gutiérrez-Santiago A, Gentico-Merino LA, Prieto-Lage I. Detection of the technicaltactical pattern of the scoring actions in judo in the men's category of $-73 \mathrm{~kg}$. Int $\mathbf{J}$ Perform Anal Sport. 2019 Sep;19(5):778-93.

22. Chwała W, Ambroży T, Sterkowicz S. Three-dimensional analysis of the ju-jitsu 
competitors' motion during the performance of the ippon-seoi-nage throw. Arch Budo Sci Martial Arts Extrem Sport. 2013;9(1).

456

457

23. Ambroży T, Piwowarski J, Badeński S. Polski Związek Ju-jitsu a bezpieczeństwo: sprawność, skuteczność, organizacja. Kraków: WSBPI Apeiron; 2013. 86-98 p.

24. Januszewki J, Żarek J. Teoria Sportu: tezy wykładów i ćwiczeń. Kraków: AWF Kraków; 1995. 28-29 p.

25. Daigo T. Kodokan judo: Throwing techniques. Londyn: Kodansha International; 2005.

26. Otaki, T., \&Draeger DF. Judo formal techniques: A complete guide to KodokanRandori no Kata. Tuttle Publ. 2019;

27. Ito K, Hirose N, Nakamura M, Maekawa N, Tamura M. Judo kumit-te pattern and technique effectiveness shifts after the 2013 International Judo Federation rule revisions. Arch Budo. 2014;10:1-9.

28. Martins FP, de Souza LSDP, de Campos RP, Bromley SJ, Takito MY, Franchini E. Techniques utilised at 2017 Judo World Championship and their classification: Comparisons between sexes, weight categories, winners and non-winners. Ido Mov Cult. 2019;19(1):58-65.

29. Dimitrova N. Major Trends in the World Judo Sport Development. Trakia J Sci [Internet]. 2020;18:848-53. Available from: http://www.uni-sz.bg

30. MURAYAMA H, HITOSUGI M, MOTOZAWA Y, OGINO M, KOYAMA K. Biomechanical Analysis of the Head Movements of a Person Thrown by the Judo Technique 'Seoi-nage.’ Neurol Med Chir (Tokyo) [Internet]. 2020;60(2):101-6. Available from: https://www.jstage.jst.go.jp/article/nmc/60/2/60_oa.2019-0206/_article 
trenera i problemy badawcze w sportach walki. In: Zesz Nauk Kraków. Kraków; 2001. p. $187-200$.

479

480

481

482

32. Sterkowicz S, Ambroży T. The fitness profile of the men who train ju-jitsu. Antropomotoryka. 1992;7:135-41.

33. Sterkowicz S. Test specjalnej sprawnosci ruchowej w judo. Special Judo Fitness Test. Antropomotoryka. 1995;12,13(29-44).

34. S S, Zuchowicz A, Kubica R. Levels of anaerobic capacity and results for Special Judo Fitness test in judo competitors. J Hum Kin. 1999;2:115-35.

35. Franchini E, Nunes AV, Moraes JM, Del Vecchio FB. Physical Fitness and Anthropometrical Profile of the Brazilian Male Judo Team. J Physiol Anthropol [Internet]. 2007;26(2):59-67. Available from: http://joi.jlc.jst.go.jp/JST.JSTAGE/jpa2/26.59?from=CrossRef

36. Almansba R, Franchini E, Sterkowicz S, Imamura RT, Calmet M, Ahmaidi S. A comparative study of speed expressed by the number of throws between heavier and lighter categories in judo. Sci Sports [Internet]. 2008 Jun;23(3-4):186-8. Available from: https://linkinghub.elsevier.com/retrieve/pii/S0765159707001487

37. Sterkowicz-Przybycień KL, Fukuda DH. Establishing Normative Data for the Special Judo Fitness Test in Female Athletes Using Systematic Review and Meta-Analysis. J Strength Cond Res [Internet]. 2014 Dec;28(12):3585-93. Available from: https://journals.lww.com/00124278-201412000-00035

38. Garbouj H, Salmi MA, Haj Sassi R, Haj Yahmed M, Chamari K, Chaouachi A. Do maximal aerobic power and blood lactate concentration affect Specific Judo Fitness Test performance in female judo athletes? Biol Sport [Internet]. 2016 Aug 
6;33(4):367-72. Available from:

http://183.indexcopernicus.com/abstracted.php?level=5\&ICID=1221890

502

503

504

505

506

507

508

509

510

511

512

513

514

515

516

39. Casals C, Huertas JR, Franchini E, Sterkowicz-Przybycień K, Sterkowicz S, GutiérrezGarcía C, et al. Special Judo Fitness Test Level and Anthropometric Profile of Elite Spanish Judo Athletes. J Strength Cond Res [Internet]. 2017 May;31(5):1229-35. Available from: https://journals.lww.com/00124278-201705000-00009

40. Arazi H, Noori M, Izadi M. Correlation of anthropometric and bio-motor attributes with Special Judo Fitness Test in senior male judokas. Ido Mov Cult. 2017;17(4):1924.

41. Agostinho MF, Olivio Junior JA, Stankovic N, Escobar-Molina R, Franchini E. Comparison of special judo fitness test and dynamic and isometric judo chin-up tests' performance and classificatory tables' development for cadet and junior athletes. J Exerc Rehabil [Internet]. 2018 Apr 26;14(2):244-52. Available from: http://ejer.org/journal/view.php?number=2013600493

42. Franchini E, Takito MY. Physical Fitness and Anthropometrical Differences. Biol Sport. 2005;22(4):315-28.

43. Sterkowicz S, Zuchowicz A, Kubica R. Levels of anaerobic and aerobic capacity indices and results for the special fitness test in judo competitors. Vol. 2, Journal of Human Kinetics. 1999. p. 115-35.

44. Drid P, Casals C, Mekic A, Radjo I, Stojanovic M, Ostojic SM. Fitness and Anthropometric Profiles of International vs. National Judo Medalists in HalfHeavyweight Category. J Strength Cond Res [Internet]. 2015 Aug;29(8):2115-21. Available from: https://journals.lww.com/00124278-201508000-00006 
45. Sterkowicz, S.; Zuchowicz, A.; Kubica R. Levels of anaerobic and aerobic capacity indices and results for the special fitness test in judo competitors. J Hum Kinet. 1999;2:115-35.

46. Sterkowicz-Przybycień K. Special fitness testing in sport ju-jitsu. Arch Budo. 2009;5:131-7.

47. Özkan I, İlkay D, Halil İC, Yıldırım İ. A new approach to Special Judo Fitness Test index: Relative index Int. J Hum Sci. 2017;14(4):4221-5.

48. Karimi M. Validity of Special Judo Fitness Test in Iranian Male Wrestlers. Int J Wrestl Sci [Internet]. 2016 Jan 2;6(1):34-8. Available from: https://www.tandfonline.com/doi/full/10.1080/21615667.2016.1172141

49. Fukuda DH, Stout JR, Kendall KL, Smith AE, Wray ME, Hetrick RP. The Effects of Tournament Preparation on Anthropometric and Sport-Specific Performance Measures in Youth Judo Athletes. J Strength Cond Res [Internet]. 2013 Feb;27(2):331-9. Available from: https://journals.lww.com/00124278-201302000-00008

50. Hashimoto T, Ishii T, Okada N, Itoh M. Impulsive force on the head during performance of typical ukemi techniques following different judo throws. J Sports Sci [Internet]. 2015 Aug 9;33(13):1356-65. Available from: http://www.tandfonline.com/doi/full/10.1080/02640414.2014.990482

51. Koshida S, Ishii T, Matsuda T, Hashimoto T. Biomechanics of judo backward breakfall for different throwing techniques in novice judokas. Eur J Sport Sci [Internet]. 2017 Apr 21;17(4):417-24. Available from: https://www.tandfonline.com/doi/full/10.1080/17461391.2016.1268652

52. Bernick C, Banks S. What boxing tells us about repetitive head trauma and the brain. 
Alzheimers Res Ther [Internet]. 2013;5(3):23. Available from:

http://alzres.biomedcentral.com/articles/10.1186/alzrt177

53. Błach W, Smolders P, Rydzik Ł, Bikos G, Maffulli N, Malliaropoulos N, et al. Judo

54. Ishikawa Y, Anata K, Hayashi H, Yokoyama T, Ono T, Okada S. Effects of Different

58. Kamitani T, Malliaropoulos NG, Omiya M, Otaka Y, Inoue K, Onidani N. On the way Injuries Frequency in Europe's Top-Level Competitions in the Period 2005-2020. J Clin Med [Internet]. 2021 Feb 19;10(4):852. Available from: https://www.mdpi.com/2077-0383/10/4/852

Throwing Techniques in Judo on Rotational Acceleration of Uke's Head. Int J Sport Heal Sci [Internet]. 2018;16:173-9. Available from:

https://www.jstage.jst.go.jp/article/ijshs/16/0/16_201713/_article

55. MURAYAMA H, HITOSUGI M, MOTOZAWA Y, OGINO M, KOYAMA K.

Rotational Acceleration during Head Impact Resulting from Different Judo Throwing Techniques. Neurol Med Chir (Tokyo) [Internet]. 2014;54(5):374-8. Available from: http://jlc.jst.go.jp/DN/JST.JSTAGE/nmc/oa.2013-

0227?lang=en \& from $=$ CrossRef $\&$ type $=$ abstract

56. MURAYAMA H, HITOSUGI M, MOTOZAWA Y, OGINO M, KOYAMA K. Ukemi Technique Prevents the Elevation of Head Acceleration of a Person Thrown by the Judo Technique ‘Osoto-gari.' Neurol Med Chir (Tokyo) [Internet]. 2020;60(6):307-12. Available from: https://www.jstage.jst.go.jp/article/nmc/60/6/60_oa.2020-0043/_article

57. Nambu S, Noji M. Case of Fatal Head Trauma Experienced During Japanese Judo. Curr Sports Med Rep [Internet]. 2014;13(1):11-5. Available from: http://journals.lww.com/00149619-201401000-00006 to the Tokyo Summer Olympic Games (2020). Prevention of severe head and neck 
injuries in judo: it's time for action. Br J Sports Med [Internet]. 2017 Nov;51(22):1581-2. Available from: https://bjsm.bmj.com/lookup/doi/10.1136/bjsports-2017-097681

59. Ambroży T, Sterkowicz-Przybycień K, Sterkowicz S, Kędra A, Mucha D, Ozimek M, et al. Differentiation of Physical Fitness in Polish Elite Sports Ju-Jitsu Athletes Physical Fitness in Elite Ju-Jitsu Athletes. J Kinesiol Exerc Sci. 2017;27(79):57-70.

60. Górski J. Fizjologia wysiłku i treningu fizycznego. Wydaw Lek PZWL. 2019;28, 74, 148.

61. Franchini E, Sterkowicz S, Szmatlan-Gabrys U, Gabrys T, Garnys M. Energy System Contributions to the Special Judo Fitness Test. Int J Sports Physiol Perform [Internet]. 2011 Sep;6(3):334-43. Available from:

https://journals.humankinetics.com/view/journals/ijspp/6/3/article-p334.xml

62. Abedelmalek S, Chtourou H, Souissi N, Tabka Z. Caloric Restriction Effect on Proinflammatory Cytokines, Growth Hormone, and Steroid Hormone Concentrations during Exercise in Judokas. Oxid Med Cell Longev [Internet]. 2015;2015:1-8. Available from: http://www.hindawi.com/journals/omc1/2015/809492/

63. Ishikawa Y, Anata K, Hayashi H, Uchimura N, Okada S. Influence of fatigue on head angular acceleration in judo high-intensity exercise. Arch Budo. 2020;16:99-106. 